\title{
PENGARUH KEMASAN TERHADAP KUALITAS DADIH SUSU SAPI
}

\section{THE EFFECT OF PACKAGING ON THE QUALITY OF COW MILK DADIH}

\author{
Miskiyah* dan Wisnu Broto \\ Balai Besar Penelitian dan Pengembangan Pascapanen Pertanian, Jl. Tentara Pelajar No. 12 A, Bogor, 16114
}

\section{INTISARI}

Pengemasan dadih hingga kini belum banyak tersentuh inovasi teknologi. Secara tradisional dadih biasanya dikemas menggunakan bambu. Tujuan penelitian untuk memperoleh jenis kemasan terbaik untuk dadih yang tahan selama penyimpanan. Rancangan percobaan yang digunakan untuk penelitian ini adalah Rancangan Acak Lengkap pola Faktorial (7 x 7). Faktor 1: jenis kemasan yaitu bambu; cup plastik pp; kemasan flexypack; gerabah; kemasan flexypack (dengan pemindahan dari bambu); gerabah (dengan pemindahan dari bambu); cup plastik pp (dengan pemindahan dari bambu). Faktor ke 2: waktu penyimpanan $(0,4,8,12,16,20$, dan 24 hari). Hasil menunjukkan bahwa kemasan terbaik untuk dadih susu sapi adalah kemasan flexypack dan cup plastik pp. Dadih susu sapi yang dikemas pada kemasan flexypack dan cup plastik pp mempunyai daya tahan hingga 24 hari pada suhu dingin (refrigerator). Namun dari segi ekonomis, kemasan cup plastik pp lebih efisien. Karakteristik dadih sapi yang dibuat menggunakan kemasan cup plastik pp antara lain total asam 1,60\%; $\mathrm{pH} 3,88$; viskositas 351,43 cPs; total padatan 14,75\%; kadar air 85,25\%; kadar abu 0,90\%; kadar protein 2,43\%; kadar lemak 3,68\%; total bakteri asam laktat (BAL) $8 \times 10^{11} \mathrm{CFU} / \mathrm{g}$. Jumlah BAL pada dadih yang dibuat menggunakan berbagai jenis kemasan $>10^{8} \mathrm{CFUs} / \mathrm{ml}$, sehingga dadih susu sapi yang diperoleh tergolong sebagai minuman probiotik. Uji organoleptik menunjukkan kemasan cup plastik pp memiliki keunggulan dalam atribut kemasan dan kemudahan mengkonsumsi. Sementara, dadih pada perlakuan bambu ke kemasan flexypack memiliki keunggulan pada warna dan aroma. Kemasan gerabah, memiliki keunggulan dalam rasa dan tekstur. Secara umum, dadih yang diminati panelis adalah dadih susu sapi yang dikemas dalam kemasan gerabah, perlakuan bambu ke kemasan flexypack, dan perlakuan bambu ke cup plastik pp.

(Kata kunci: Dadih, Kemasan, Kualitas)

\section{ABSTRACT}

Dadih is a traditional dairy product obtained from a fermentation of buffalo milk and usually packed using bamboo. The usage of bamboo for dadih packaging has limitation in transportation and storage life. This study aimed to examine the effect of packaging material to dadih quality produced from cow milk during storage. Experimental design used at this study was Completely Randomized Design with Factorial pattern (7 x 7). The first factor is packaging material that are bamboo; cup plastic pp; flexypack packaging; clay; flexypack packaging (with evacuation from bamboo); clay (with evacuation from bamboo); cup plastic pp (with evacuation from bamboo). The second factor is storage time $(0,4,8,12,16,20$, and 24 days). Result showed that best packaging to cow milk dadih is flexypack and cup plastic pp. Cow milk dadih that was packed in flexypack and cup plastic pp had storage life up to 24 days at cold temperature (refrigerator). From the perspective of economic, cup plastic pp packaging showed most efficient packaging. Characteristic of cow milk dadih packaged in cup plastic pp were total of titratable acid 1,60\%; pH 3,88; viscocity 351,43 cPs; total solid 14,75\%; water content 85,25\%; ash content 0,90\%; protein content 2,43\%; fat content 3,68\%; total of lactic acid bacteria (LAB) at $8 \times 10^{11} \mathrm{CFUs} / \mathrm{g}$. Total LAB at dadih packaged in other kinds of packaging were $>10^{8} \mathrm{CFUs} / \mathrm{ml}$. Organoleptic test showed that cup plastic pp packaging had excellence in tidiness attribute and consumption amenity. Meanwhile, curd of dadih packaged in bamboo and flexypack had excellent at color and aroma. Clay packaging had excellence in mouthfell and texture. In general, the first priority of dadih choosen by panelist was cow milk dadih packed in clay packaging, bamboo treatment to flexypack packaging, and bamboo treatment to cup plastic pp.

(Keyword: Dadih, Packaging, Quality)

\footnotetext{
* Korespondensi (corresponding author):

Telp. +62 8121038891

E-mail: miski_pascapanen2005@yahoo.co.id
} 


\section{Pendahuluan}

Dadih adalah salah satu produk olahan susu kerbau yang diproses secara tradisional di daerah Sumatera Barat. Dadih mempunyai kandungan protein sebesar 39,8\% dengan kandungan asam amino esensial yang cukup lengkap, kalsium, serta vitamin $\mathrm{B}$ dan $\mathrm{K}$ yang terbentuk selama proses fermentasi. Selain itu mengandung bakteri asam laktat (Lactobacillus casei subsp casei, Leuconoctoc paramasentereroides, Enterococcus faecalis subspesies liquefaciens, Lactococcus lactis subsp lactis) (Pato, 2003). BAL pada dadih selain menunjukkan aktivitas anti-mutagenik juga mampu menurunkan kadar kolesterol darah baik secara in vitro $( \pm 34 \%)$ maupun in vivo (Suryono, 2003; Surono dan Hosono, 1996; Rusfidra, 2006).

Dadih merupakan makanan bergizi tinggi, namun belum dikenal secara luas seperti halnya keju, yoghurt, atau kefir. Hal ini dikarenakan penggunaan kemasan bambu mempersulit dalam pengangkutan dan peredarannya. Selain itu dadih dalam kemasan bambu mempunyai masa simpan yang terbatas, sehingga memerlukan inovasi teknologi pengemasan untuk mendorong pemasaran dadih. Penggunaan jenis kemasan lain dalam pembuatan dadih mulai dikembangkan, misalnya penggunaan cup plastik (Sisriyenni dan Yayu, 2004), gerabah, dan kemasan fleksibel. Hal ini perlu dilakukan agar konsumen tertarik untuk mengkonsumsinya. Selain itu untuk meningkatkan citra produk tidak hanya sebagai produk lokal saja, namun merupakan produk yang bermanfaat bagi kesehatan. Dengan demikian perbaikan kemasan diharapkan memudahkan peredaran dan konsumsi dadih.

Pengemasan dadih oleh perajin di Sumatera Barat masih menggunakan bambu, yaitu bambu gombong (Gigantochloa verticilata) dan bambu ampel (Bambusa vulgaris) (Suryono, 2003). Hingga saat ini belum banyak tersentuh oleh inovasi teknologi. Dadih sebagai pangan tradisional berwarna putih kekuningan, memiliki aroma dan citarasa asam serta tampilan khas yang diduga karena pengaruh bambu sebagai kemasannya. Masa simpan dan kesulitan dalam pemasaran dadih dalam tabung bambu terbatas, sehingga dengan melakukan modifikasi melalui pengemasan diharapkan dapat mengembangkan pemasaran dadih semakin meluas dan mempertahankan masa simpannya seperti halnya susu fermentasi.

Bambu yang digunakan sebagai wadah untuk pembuatan dadih dipilih yang sudah tua sehingga kadar air bambu relatif rendah, sehingga kualitas dadih lebih baik (Sayuti, 1992). Dalam pembuatannya bambu dipotong kurang lebih 1,5 ruas dan ruas bagian atas dilubangi sedikit kira-kira sebesar jari. Selanjutnya dibersihkan dan dibalikkan untuk membuang kotoran yang terdapat pada tabung bambu. Peneliti lain menggunakan bambu untuk pembuatan dadih dengan ukuran $\pm 15 \mathrm{~cm}$ dan diameter $\pm 4-5 \mathrm{~cm}$ (Dzarniza, 1999).

Kemasan berperan penting untuk mempertahankan kualitas suatu produk. Proses pengemasan dianggap sebagai bagian integral dari proses produksi. Fungsi kemasan antara lain sebagai wadah untuk menempatkan produk, memberikan perlindungan terhadap produk, dan menambah daya tarik produk (Syarief dan Irawati, 1988). Pendapat lain menyebutkan bahwa fungsi kemasan adalah: 1) dapat melindungi dan mempertahankan kualitas isinya terhadap pengaruh dari luar, 2) tidak berpengaruh terhadap isi, 3) terbuat dari bahan yang tidak melepaskan bagian atau unsur yang dapat mengganggu kesehatan atau mempengaruhi kualitas, 4) menjamin keutuhan dan keaslian isinya, 5) tahan terhadap perlakuan selama pengolahan pengangkutan dan peredaran, dan 6) tidak boleh merugikan atau membahayakan konsumen (Julianto, 2006).

Kemasan flexypack merupakan suatu bentuk kemasan yang bersifat fleksibel, terbentuk dari lapisan aluminium foil, film plastik, selopan, film plastik berlapis logam aluminium (metalized film) dan kertas. Pada umumnya jenis kemasan ini digunakan untuk mengemas berbagai produk baik padat maupun cair. Kemasan fleksibel juga dapat menggantikan kemasan rigid maupun kemasan kaleng, selain lebih ekonomis juga mudah dalam penanganannya (Anonimus, 2007). Penggunaan kemasan gerabah (clay pot) lazim digunakan di Afrika Selatan untuk mengemas susu fermentasi (Beukes et al., 2000).

Polipropilen $(p p)$ termasuk jenis plastik olefin dengan sifat-sifat dan penggunaan sangat mirip dengan polietilen ( $p e$ ), yaitu: ringan dengan densitas $0,9 \mathrm{~g} / \mathrm{cm}^{3}$; mudah dibentuk; dapat tembus pandang dan jernih dalam bentuk film; lebih kuat dan lebih kaku dari pe sehingga tidak mudah sobek; mudah dalam penanganan dan distribusi; permeabilitas terhadap uap air rendah, permeabilitas terhadap gas sedang; tidak baik untuk bahan pangan yang mudah rusak oleh oksigen; tahan terhadap suhu tinggi sampai dengan $150^{\circ} \mathrm{C}$ sehingga dapat dipakai untuk mensterilkan bahan pangan; mempunyai titik lebur yang tinggi sehingga sulit untuk dibentuk menjadi kantung dengan sifat kelim panas yang baik. Polipropylen juga tahan lemak, asam kuat dan basa, sehingga baik untuk kemasan minyak dan sari buah. Kemasan $p p$ pada suhu kamar tidak terpengaruh oleh pelarut kecuali oleh $\mathrm{HCl}$, sedangkan pada suhu tinggi akan bereaksi dengan benzen, siklen, toluen, terpentin dan asam nitrat kuat (Julianto, 2006). Informasi mengenai jenis kemasan yang tepat untuk 
dadih belum banyak didapat. Penelitian bertujuan untuk mengetahui pengaruh jenis kemasan terhadap kualitas dadih selama penyimpanan.

\section{Materi dan Metode}

\section{Materi}

Bahan yang digunakan terdiri dari susu sapi segar yang diperoleh dari Fakultas Peternakan IPB, susu skim, carboxymethyl cellulose (CMC), Lactobacillus casei (L. casei) yang diisolasi dari dadih asal Sumatera Barat. L. casei merupakan salah satu bakteri yang teridentifikasi terdapat pada dadih dan memberikan karakteristik terbaik untuk pembuatan dadih susu sapi dibandingkan starter BAL lain asal dadih, cup plastik polypropilen ( $p p$ ), bambu gombong, kemasan flexypack, gerabah, media deMan Rogosa and Sharpe A (MRS A) dan MRS $\mathrm{B}$, bahan kimia lain untuk analisis.

\section{Metode}

Prosedur pembuatan dadih. Metode pembuatan berdasarkan modifikasi dari penelitian sebelumnya (Taufik, 2004; Sunarlim dan Usmiati, 2006). Susu sapi segar ditambah dengan susu skim (3\%) dan CMC (1\%) diaduk dengan mixer dan dipasteurisasi untuk kemudian didinginkan sampai suhu $\pm 37^{\circ} \mathrm{C}$, kemudian ditambah starter L. casei (3\%). Susu campuran tersebut dimasukkan ke dalam tabung bambu, gerabah, flexypack dan cup plastik polypropilen ( $p p$ ) dengan volume masingmasing $100 \mathrm{ml}$, kemudian difermentasi selama 48 jam pada suhu kamar. Kemasan sebelumnya dilakukan sterilisasi, dengan cara dicelupkan ke dalam air panas dan ditiriskan. Selain menggunakan kemasan utama, perlakuan kemasan juga dilakukan dengan cara memindahkan susu yang sudah difermentasi pada tabung bambu selama 15 jam, ke dalam kemasan gerabah, flexypack, dan cup plastik $p p$. Fermentasi awal selama 15 jam merupakan hasil penelitian sebelumnya, yang ditunjukkan dengan konsistensi dadih yang paling baik. Proses fermentasi dilanjutkan sampai 48 jam. Dadih yang telah terbentuk disimpan pada refrigerator $\left( \pm 4^{\circ} \mathrm{C}\right)$. Pengamatan parameter dilakukan pada $0,4,8,12$, 16, 20, dan 24 hari.

Pengujian mutu dadih. Dadih yang dikemas dengan berbagai jenis kemasan tersebut selanjutnya diamati mutu fisikokimia yang meliputi total asam (Antherton dan Newlander, 1980), pH (Apriyantono et al., 1989), total padatan, viskositas, proksimat (AOAC, 1984), mutu mikrobiologi yaitu total BAL (Fardiaz, 1989) dan mutu organoleptik (Soekarto dan Hubeis, 1991).
Pengujian organoleptik dilakukan oleh 25 orang panelis tidak terlatih terhadap dadih dalam berbagai kemasan tersebut. Pengujian tersebut dilakukan ketika dadih susu sapi telah terbentuk. Panelis diminta menilai dadih yang telah dibuat yang meliputi kemudahan dalam mengkonsumsi, warna, aroma, tekstur, rasa, dan penerimaan umum. Panelis diharapkan dapat menanggapi persepsi kesukaannya pada sampel, dan mentransformasi dalam 5 tingkat skor penilaian kesukaan yaitu suka (5), agak suka (4), netral (3), agak tidak suka (2), dan tidak suka (1), sedangkan untuk kemudahan mengkonsumsi ditransformasi dalam 5 tingkat penilaian meliputi mudah (5), agak mudah (4), netral (3), agak sulit (2), dan sulit (1).

Analisis statistik. Rancangan percobaan yang digunakan untuk penelitian ini adalah Rancangan Acak Lengkap pola faktorial, sebagai faktor 1 adalah jenis kemasan yaitu bambu, cup plastik $p p$, kemasan flexypack, gerabah, kemasan flexypack (dengan pemindahan dari bambu), gerabah (dengan pemindahan dari bambu), cup plastik $p p$ (dengan pemindahan dari bambu), sedangkan faktor ke 2 adalah waktu simpan $(0,4,8$, 12, 16, 20, dan 24 hari). Percobaan dilakukan dengan 2 kali ulangan. Data dianalisis menggunakan analisis ragam (ANOVA), dan jika menunjukkan perbedaan pengaruh yang nyata dilakukan uji lanjut dengan Duncan's New Multiple Range Test dengan tingkat kepercayaan $95 \%$.

\section{Hasil dan Pembahasan}

\section{Karakteristik bahan baku}

Pengujian mutu susu sapi dan campurannya setelah pasteurisasi dilakukan untuk menentukan kelayakannya sebagai bahan baku pembuatan dadih. Tabel 1 menunjukkan bahwa perlakuan pasteurisasi dan bahan pencampur (antara lain susu skim) menyebabkan perubahan komposisi dari susu pasteurisasi yaitu penurunan kadar air dan peningkatan kadar protein, total asam, $\mathrm{pH}$ dan padatan terlarut.

Efek pemanasan selama pasteurisasi menjadi penyebab turunnya kadar air, sedangkan perubahan kadar protein, total asam, $\mathrm{pH}$ dan padatan terlarut diduga karena adanya penambahan susu skim (Saleh, 2004), yang mengandung semua zat makanan kecuali lemak dan vitamin-vitamin yang larut dalam lemak. Selain itu, susu skim merupakan susu bubuk yang dapat mempengaruhi pembentukan koagulan. Komposisi susu tersebut diduga mampu menghasilkan dadih sesuai dengan karakteristik yang diinginkan, yaitu semi padat. 
Tabel 1. Karakteristik susu segar yang digunakan (characteristic of fresh milk used)

\begin{tabular}{|c|c|c|c|c|}
\hline Parameter mutu (quality parameter) & $\begin{array}{l}\text { Susu } \\
\text { segar } \\
\text { (fresh } \\
\text { milk) }\end{array}$ & $\begin{array}{l}\text { SNI 01-3141- } \\
\text { 1998 } \\
\text { (SNI susu } \\
\text { segar) } \\
\text { (Indonesian } \\
\text { national } \\
\text { standard of } \\
\text { fresh milk) }^{1}\end{array}$ & $\begin{array}{l}\text { Susu sapi dan } \\
\text { susu skim } \\
\text { setelah } \\
\text { dipasteurisasi } \\
\text { (fresh milk and } \\
\text { skim milk after } \\
\text { pasteurization) }\end{array}$ & $\begin{array}{l}\text { SNI 01-3951-1995 } \\
\text { (SNI susu } \\
\text { pasteurisasi) } \\
\text { (Indonesian } \\
\text { national standard } \\
\text { of pasteurized } \\
\text { milk) }^{2}\end{array}$ \\
\hline Kadar air (\%) (water content $(\%))$ & 89,02 & - & 85,00 & - \\
\hline Kadar protein $(\%)($ protein content $(\%))$ & 02,23 & minimal 2,7 & 03,40 & 2,5 \\
\hline Kadar lemak (\%) (fat content (\%)) & 04,50 & minimal 3 & 04,50 & 7,7 \\
\hline Total asam (\%) (titratable acid (\%)) & 00,15 & - & 00,16 & - \\
\hline $\mathrm{pH}$ & 06,62 & $6-7$ & 06,68 & - \\
\hline Total padatan (\%) (total solid (\%)) & 10,98 & - & 15,00 & - \\
\hline
\end{tabular}

\section{Karakteristik fisikokimia dadih}

Total asam. Hasil analisis menunjukkan bahwa terdapat adanya interaksi antara jenis kemasan dan waktu simpan $(\mathrm{P}<0,05)$. Secara tunggal jenis kemasan dan waktu simpan mempengaruhi total asam dadih. Penggunaan jenis kemasan menunjukkan total asam yang tidak berbeda pada hari ke 4,8 , dan 24 , demikian juga pada penyimpanan hari ke 0 dan 16 , namun jika dibandingkan pada hari ke 12 dan 20 menunjukkan total asam yang berbeda $(\mathrm{P}<0,05)$. Nilai total asam diduga dipengaruhi oleh aktivitas $L$. casei pada dadih selama proses perubahan laktosa susu menjadi asam laktat. Semakin lama produk disimpan maka semakin banyak asam laktat yang dihasilkan sehingga total asam menjadi meningkat. Penambahan starter BAL menyebabkan mutu dan citarasa dadih yang dihasilkan lebih konsisten dibandingkan dengan dadih asli tanpa inokulasi kultur (Sunarlim dan Usmiati, 2006).

Kisaran nilai total asam dadih hasil penelitian (Tabel 2) memenuhi standar mutu SNI yoghurt (SNI No 01-2981-1992), yaitu 0,5-2\%, namun sedikit berbeda jika dibandingkan dengan dadih susu kerbau (1,42\%) (Sugitha, 1995). Perbedaan tersebut diduga karena pada dadih susu sapi hanya menggunakan starter BAL L. casei sehingga pembentukan asam laktat hasil fermentasi cenderung lebih banyak dibandingkan dadih susu kerbau.

pH. Hasil analisis menunjukkan bahwa terdapat adanya interaksi antara jenis kemasan dan waktu simpan $(\mathrm{P}<0,05)$. Secara tunggal jenis kemasan dan waktu simpan mempengaruhi total $\mathrm{pH}$ dadih. Penggunaan kemasan fleksibel dan cup plastik $p p$ menunjukkan $\mathrm{pH}$ yang secara statistik tidak berbeda (Tabel 3). Lama waktu simpan cenderung menyebabkan pH turun. Komponen susu yang paling berperan dalam fermentasi adalah laktosa dan kasein yang digunakan sebagai sumber energi dan karbon yang nantinya akan diubah oleh BAL menjadi asam laktat. Asam laktat tersebut diduga menyebabkan keasaman dadih susu sapi meningkat atau $\mathrm{pH}$ menurun. Kisaran nilai $\mathrm{pH}$ dadih memenuhi standar SNI yoghurt, yaitu minimal 3,4 sedangkan jika dibandingkan dengan dadih susu kerbau cukup berbeda yaitu 4,1 (Yudoamijoyo et al., 1983).

Viskositas. Hasil analisis ragam menunjukkan bahwa secara tunggal hanya jenis kemasan yang mempengaruhi viskositas dadih $(\mathrm{P}<0,05)$, sedangkan waktu simpan tidak mempengaruhi viskositas dadih susu sapi, seperti tersaji pada Tabel 4. Nilai viskositas dadih susu sapi pada tiap perlakuan kemasan jauh lebih tinggi dibandingkan dengan nilai viskositas susu segar yang hanya sekitar $16 \mathrm{cP}$. Hal ini disebabkan oleh tingginya total padatan susu yang menjadi bahan baku dadih setelah mengalami penambahan susu skim dan juga CMC sebagai pengental. Sesuai dengan penelitian sebelumnya (Taufik, 2004), nilai viskositas dadih lebih tinggi dibandingkan dengan nilai viskositas susu segar karena tingginya total padatan susu yang menjadi bahan baku dadih, namun bila dibandingkan dengan viskositas dadih susu kerbau yang berkisar $360 \mathrm{cPs}$ maka hanya penggunaan kemasan dari bambu yang mempunyai nilai viskositas mendekati.

Kadar air dan total padatan. Hasil analisis menunjukkan bahwa terdapat interaksi antara jenis kemasan dan waktu simpan terhadap kadar air dan total padatan dadih susu sapi $(\mathrm{P}<0,05)$ (Tabel 5 dan 6). Dadih yang dikemas dalam gerabah baik yang langsung maupun yang difermentasi dalam bambu terlebih dahulu memiliki kadar air rendah dan total padatan tinggi. Hal ini diduga karena gerabah merupakan kemasan alami yang mudah menyerap 
Tabel 2. Pengaruh berbagai jenis kemasan terhadap total asam (\%) dadih susu sapi (effect of various packaging on titratable acid (\%) of cow milk dadih)

\begin{tabular}{lccccccc}
\hline \hline \multirow{2}{*}{ Bahan pengemasan (packaging material) } & \multicolumn{6}{c}{ Lama penyimpanan (hari) (storage periode (days) } \\
\cline { 2 - 8 } & 0 & 4 & 8 & 12 & 16 & 20 & 24 \\
\hline Bambu (bamboo) & $1,43^{\mathrm{a}}$ & $1,63^{\mathrm{b}}$ & $1,64^{\mathrm{b}}$ & $1,75^{\mathrm{d}}$ & $1,44^{\mathrm{a}}$ & $1,71^{\mathrm{e}}$ & $1,51^{\mathrm{b}}$ \\
Kemasan flexypack (flexypack packaging) & $1,35^{\mathrm{a}}$ & $1,55^{\mathrm{b}}$ & $1,56^{\mathrm{b}}$ & $1,54^{\mathrm{d}}$ & $1,53^{\mathrm{a}}$ & $1,83^{\mathrm{e}}$ & $1,63^{\mathrm{b}}$ \\
Bambu ke kemasan flexypack (bamboo to & $1,62^{\mathrm{a}}$ & $1,63^{\mathrm{b}}$ & $1,55^{\mathrm{b}}$ & $1,70^{\mathrm{d}}$ & $1,51^{\mathrm{a}}$ & $1,91^{\mathrm{e}}$ & $1,69^{\mathrm{b}}$ \\
flexypack packaging) & & & & & & & \\
Cup plastik pp (pp plastic cup) & $135^{\mathrm{a}}$ & $1,48^{\mathrm{b}}$ & $1,69^{\mathrm{b}}$ & $1,82^{\mathrm{d}}$ & $1,41^{\mathrm{a}}$ & $1,75^{\mathrm{e}}$ & $1,67^{\mathrm{b}}$ \\
Bambu ke cup plastik pp (bamboo to pp & $1,54^{\mathrm{a}}$ & $1,59^{\mathrm{b}}$ & $1,75^{\mathrm{b}}$ & $1,91^{\mathrm{d}}$ & $1,08^{\mathrm{a}}$ & $1,95^{\mathrm{e}}$ & $1,77^{\mathrm{b}}$ \\
plastic cup) & & & & & & & \\
Gerabah (clay) & $1,43^{\mathrm{a}}$ & $1,81^{\mathrm{b}}$ & $1,51^{\mathrm{b}}$ & na & na & na & na \\
Bambu ke gerabah (bamboo to clay) & $1,56^{\mathrm{a}}$ & $1,65^{\mathrm{b}}$ & $2,60^{\mathrm{b}}$ & na & na & na & na \\
\hline
\end{tabular}

$\overline{\mathrm{a}, \mathrm{b}, \mathrm{d}, \mathrm{e}}$ Superskrip yang berbeda pada baris/kolom yang sama menunjukkan perbedaan yang nyata $(\mathrm{P}<0,05)$

(different superscripts at the same row/column indicate significant differences $(P<0.05)$ ).

na: tidak memungkinkan untuk diuji (not available to be tested).

Tabel 3. Pengaruh berbagai jenis kemasan terhadap pH dadih susu sapi (effect of various packaging on $\mathrm{pH}$ of cow milk dadih)

\begin{tabular}{lcccccccc}
\hline \hline \multirow{2}{*}{ Bahan pengemasan (packaging material) } & \multicolumn{6}{c}{ Lama penyimpanan (hari) (storage periode (days)) } \\
\cline { 2 - 8 } & 0 & 4 & 8 & 12 & 16 & 20 & 24 \\
\hline Bambu (bamboo) & $4,19^{\mathrm{a}}$ & $3,88^{\mathrm{b}}$ & $3,93^{\mathrm{c}}$ & $3,74^{\mathrm{d}}$ & $4,06^{\mathrm{e}}$ & $3,86^{\mathrm{f}}$ & $4,08^{\mathrm{d}}$ \\
Kemasan flexypack (flexypack packaging) & $4,07^{\mathrm{b}}$ & $3,92^{\mathrm{a}}$ & $3,90^{\mathrm{d}}$ & $3,88^{\mathrm{e}}$ & $3,92^{\mathrm{c}}$ & $3,74^{\mathrm{g}}$ & $3,78^{\mathrm{e}}$ \\
Bambu ke kemasan flexypack (bamboo to & $3,95^{\mathrm{c}}$ & $3,87^{\mathrm{d}}$ & $3,83^{\mathrm{a}}$ & $3,85^{\mathrm{b}}$ & $3,88^{\mathrm{f}}$ & $3,71^{\mathrm{e}}$ & $3,77^{\mathrm{b}}$ \\
flexypack packaging) & & & & & & & & \\
Cup plastik pp (pp plastic cup) & $4,06^{\mathrm{b}}$ & $3,94^{\mathrm{a}}$ & $3,83^{\mathrm{d}}$ & $3,85^{\mathrm{e}}$ & $3,98^{\mathrm{c}}$ & $3,74^{\mathrm{g}}$ & $3,75^{\mathrm{e}}$ \\
Bambu ke cup plastik pp (bamboo to pp & $3,97^{\mathrm{d}}$ & $3,87^{\mathrm{e}}$ & $3,79^{\mathrm{b}}$ & $3,71^{\mathrm{a}}$ & $3,87^{\mathrm{g}}$ & $3,63^{\mathrm{h}}$ & $3,72^{\mathrm{a}}$ \\
plastic cup) & & & & & & & & \\
Gerabah (clay) & $4,11^{\mathrm{e}}$ & $3,96^{\mathrm{f}}$ & na & na & na & na & na \\
Bambu ke gerabah/bamboo to clay & $4,05^{\mathrm{a}}$ & $3,90^{\mathrm{b}}$ & na & na & na & na & na \\
a,b,c,d,e,f,g,h Superskrip yang berbeda pada baris/kolom yang sama menunjukkan perbedaan yang nyata $(\mathrm{P}<0,05)$ \\
(different superscripts at the same row/column indicate significant differences $(P<0.05)$ ). \\
na: tidak memungkinkan untuk diuji (not available to be tested).
\end{tabular}

na: tidak memungkinkan untuk diuji (not available to be tested).

Tabel 4. Pengaruh berbagai jenis kemasan terhadap viskositas (cPs) dadih susu sapi (effect of various packaging on viscosity (cPs) of cow milk dadih)

\begin{tabular}{|c|c|c|c|c|c|c|c|}
\hline \multirow{2}{*}{ Bahan pengemasan (packaging material) } & \multicolumn{7}{|c|}{ Lama penyimpanan (hari) (storage periode (days)) } \\
\hline & 0 & 4 & 8 & 12 & 16 & 20 & 24 \\
\hline Bambu (bamboo) & $240^{\mathrm{ab}}$ & $260^{\mathrm{ab}}$ & $360^{\mathrm{ab}}$ & $320^{\mathrm{ab}}$ & $440^{\mathrm{ab}}$ & $200^{\mathrm{ab}}$ & na \\
\hline Kemasan flexypack (flexypack packaging) & $280^{\mathrm{cd}}$ & $600^{\mathrm{cd}}$ & $840^{\mathrm{cd}}$ & $720^{\text {cd }}$ & $440^{\mathrm{cd}}$ & $320^{\mathrm{cd}}$ & $480^{\text {cd }}$ \\
\hline $\begin{array}{l}\text { Bambu ke kemasan flexypack (bamboo to } \\
\text { flexypack packaging) }\end{array}$ & $80^{\mathrm{a}}$ & $120^{\mathrm{a}}$ & $120^{\mathrm{a}}$ & $200^{\mathrm{a}}$ & $80^{\mathrm{a}}$ & $40^{\mathrm{a}}$ & $60^{\mathrm{a}}$ \\
\hline Cup plastik pp (pp plastic cup) & $380^{\mathrm{bc}}$ & $400^{\mathrm{bc}}$ & $320^{\mathrm{bc}}$ & $420^{\mathrm{bc}}$ & $440^{\mathrm{bc}}$ & $100^{\mathrm{bc}}$ & $400^{\mathrm{bc}}$ \\
\hline $\begin{array}{l}\text { Bambu ke cup plastik pp (bamboo to pp } \\
\text { plastic cup) }\end{array}$ & $120^{\mathrm{a}}$ & $120^{\mathrm{a}}$ & $160^{\mathrm{a}}$ & $80^{\mathrm{a}}$ & $160^{\mathrm{a}}$ & $80^{\mathrm{a}}$ & $80^{\mathrm{a}}$ \\
\hline Gerabah (clay) & $1120^{\mathrm{d}}$ & $160^{\mathrm{d}}$ & na & na & na & na & na \\
\hline Bambu ke gerabah (bamboo to clay) & $300^{\mathrm{bc}}$ & $400^{\mathrm{bc}}$ & na & na & na & na & na \\
\hline
\end{tabular}


air, sehingga air yang terdapat pada dadih terserap ke dalam dinding gerabah, menyebabkan kandungan air pada dadih berkurang. Bambu juga merupakan kemasan alami yang tidak kedap air, namun sifat porositasnya lebih rendah dibandingkan gerabah. Bambu gombong mempunyai daya serap air tinggi, namun hal inilah yang menjadi keunggulannya karena akan menyebabkan mutu dadih yang lebih baik (Sayuti, 1992). Kemasan fleksibel dan cup plastik $p p$ relatif tahan terhadap air karena mempunyai sifat permeabilitas terhadap uap air dan udara (Winarno, 1987), sehingga kandungan air pada cup plastik $p p$ dan kemasan fleksibel selama penyimpanan cenderung konstan.

Selama penyimpanan terjadi perubahan kadar air dan total padatan. Penurunan kadar air diduga dipengaruhi oleh penambahan starter dan susu skim pada pembuatan dadih susu sapi. Dimana penurunan kadar air diikuti dengan meningkatnya total padatan. Proses penguapan/toning pada susu dapat meningkatkan total padatan dadih, demikian juga penggunaan kemasan yang mempunyai permeabilitas air tinggi seperti gerabah.
Kadar abu. Hasil analisis ragam menunjukkan interaksi antara jenis kemasan dan waktu simpan terhadap kadar abu dadih susu sapi $(\mathrm{P}<0,05)$ (Tabel 7). Gerabah cenderung menyerap air pada dadih sehingga saat dianalisis kadar airnya rendah dan yang terukur hanya mineral saja, karena mineral tersebut tidak larut (Soeharsono, 1996), sehingga nilai kadar abunya pun menjadi tinggi. Dijelaskan pula bahwa kadar abu terdiri dari beberapa unsur mineral diantaranya kalsium (25\%), magnesium (20\%), dan fosfor (44\%).

Kadar protein. Hasil analisis menunjukkan adanya interaksi antara jenis kemasan dan waktu simpan (Tabel 8). Selama penyimpanan terjadi perubahan kadar protein, diduga protein yang terdapat pada susu juga digunakan sebagai sumber nutrisi oleh bakteri starter, sehingga semakin lama penyimpanan kadar protein akan turun.

Kadar lemak. Hasil analisis menunjukkan adanya interaksi antara jenis kemasan dan waktu simpan terhadap kadar lemak dadih susu sapi $(\mathrm{P}<0,05)$ (Tabel 9). Rerata kadar lemak semua perlakuan kemasan cenderung menurun selama

Tabel 5. Pengaruh berbagai jenis kemasan terhadap kadar air (\%) dadih susu sapi (effect of various packaging on water content (\%) of cow milk dadih)

\begin{tabular}{|c|c|c|c|c|}
\hline \multirow[t]{2}{*}{ Bahan pengemasan (packaging material) } & \multicolumn{4}{|c|}{$\begin{array}{l}\text { lama penyimpanan (hari) } \\
\text { (storage periode (days)) }\end{array}$} \\
\hline & 0 & 12 & 20 & 24 \\
\hline Bambu (bamboo) & $85,54^{\mathrm{a}}$ & $83,65^{\mathrm{b}}$ & $82,00^{\mathrm{a}}$ & $82,13^{\mathrm{a}}$ \\
\hline Kemasan flexypack (flexypack packaging) & $85,66^{\mathrm{a}}$ & $85,44^{\mathrm{b}}$ & $85,13^{\mathrm{a}}$ & $85,09^{\mathrm{a}}$ \\
\hline Bambu ke kemasan flexypack (bamboo to flexypack packaging) & $85,88^{\mathrm{a}}$ & $85,99^{\mathrm{b}}$ & $85,31^{\mathrm{a}}$ & $85,67^{\mathrm{a}}$ \\
\hline Cup plastik pp (pp plastic cup) & $85,85^{\mathrm{a}}$ & $85,44^{\mathrm{b}}$ & $85,38^{\mathrm{a}}$ & $84,34^{\mathrm{a}}$ \\
\hline Bambu ke cup plastik pp (bamboo to pp plastic cup) & $85,76^{\mathrm{a}}$ & $85,46^{\mathrm{b}}$ & $85,06^{\mathrm{a}}$ & $85,19^{\mathrm{a}}$ \\
\hline Gerabah (clay) & $72,40^{\mathrm{b}}$ & $21,12^{\mathrm{a}}$ & na & na \\
\hline Bambu ke gerabah (bamboo to clav) & $78,22^{\mathrm{b}}$ & $20,08^{\mathrm{a}}$ & na & na \\
\hline
\end{tabular}

Tabel 6. Pengaruh berbagai jenis kemasan terhadap total padatan (\%) dadih susu sapi (effect of various packaging on total solid (\%) of cow milk dadih)

\begin{tabular}{lcccc}
\hline \hline \multirow{2}{*}{ Bahan pengemasan (packaging material) } & \multicolumn{3}{c}{ lama penyimpanan (hari) } \\
\cline { 2 - 5 } (storage periode (days))
\end{tabular}

${ }^{\mathrm{a}, \mathrm{b}}$ Superskrip yang berbeda pada baris/kolom yang sama menunjukkan perbedaan yang nyata $(\mathrm{P}<0,05)$

(different superscripts at the same row/column indicate significant differences $(P<0.05)$ ).

na: tidak memungkinkan untuk diuji (not available to be tested). 
Tabel 7. Pengaruh berbagai jenis kemasan terhadap kadar abu (\%) dadih susu sapi (effect of various packaging on ash content (\%) of cow milk dadih)

\begin{tabular}{lccccc}
\hline \multirow{2}{*}{ Bahan pengemasan (packaging material) } & \multicolumn{4}{c}{ lama penyimpanan (hari) } \\
& \multicolumn{4}{c}{ (storage periode (days)) } \\
\cline { 2 - 5 } & 0 & 12 & 20 & 24 \\
\hline Bambu (bamboo) & $0,90^{\mathrm{a}}$ & $1,03^{\mathrm{c}}$ & $0,89^{\mathrm{e}}$ & $1,00^{\mathrm{ae}}$ \\
Kemasan flexypack (flexypack packaging) & $0,92^{\mathrm{ab}}$ & $0,89^{\mathrm{cd}}$ & $0,71^{\mathrm{ef}}$ & $0,79^{\mathrm{abef}}$ \\
Bambu ke kemasan flexypack (bamboo to flexypack packaging) & $0,93^{\mathrm{ab}}$ & $0,92^{\mathrm{cd}}$ & $0,97^{\mathrm{ef}}$ & $0,90^{\mathrm{abef}}$ \\
Cup plastik pp (pp plastic cup) & $0,79^{\mathrm{ab}}$ & $0,92^{\mathrm{cd}}$ & $0,95^{\mathrm{ef}}$ & $0,92^{\mathrm{abef}}$ \\
Bambu ke cup plastik pp (bamboo to pp plastic cup) & $0,92^{\mathrm{b}}$ & $0,95^{\mathrm{d}}$ & $0,50^{\mathrm{f}}$ & $0,83^{\mathrm{bf}}$ \\
Gerabah (clay) & $1,13^{\mathrm{b}}$ & $1,96^{\mathrm{d}}$ & na & na \\
Bambu ke gerabah (bamboo to clay) & $0,99^{\mathrm{c}}$ & $1,71^{\mathrm{e}}$ & na & na \\
\hline a,b,c,d,e,f
\end{tabular}

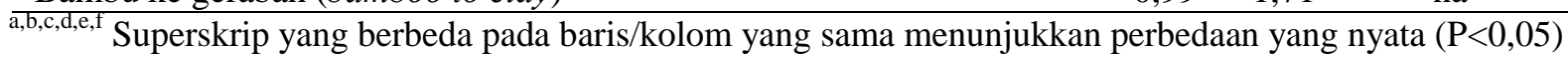

(different superscripts at the same row/column indicate significant differences $(P<0.05)$ ).

na: tidak memungkinkan untuk diuji (not available to be tested).

Tabel 8. Pengaruh berbagai jenis kemasan terhadap kadar protein (\%) dadih susu sapi (effect of various packaging on protein content (\%) of cow milk dadih)

\begin{tabular}{lcccc}
\hline \hline \multirow{2}{*}{ Bahan pengemasan (packaging material) } & \multicolumn{3}{c}{ lama penyimpanan (hari) } \\
\cline { 2 - 5 } & \multicolumn{3}{c}{ (storage periode (days)) } \\
\cline { 2 - 5 } & $2,06^{\mathrm{ab}}$ & $2,47^{\mathrm{cd}}$ & $3,51^{\mathrm{cd}}$ & $\mathrm{na}$ \\
\hline Bambu (bamboo) & $2,97^{\mathrm{a}}$ & $2,66^{\mathrm{c}}$ & $1,12^{\mathrm{c}}$ & $1,46^{\mathrm{ac}}$ \\
Kemasan flexypack (flexypack packaging) & $1,85^{\mathrm{a}}$ & $2,29^{\mathrm{c}}$ & $2,98^{\mathrm{c}}$ & $1,95^{\mathrm{ac}}$ \\
Bambu ke kemasan flexypack (bamboo to flexypack packaging) & $2,72^{\mathrm{a}}$ & $1,31^{\mathrm{c}}$ & $1,93^{\mathrm{c}}$ & $1,77^{\mathrm{ac}}$ \\
Cup plastik pp (pp plastic cup) & $1,58^{\mathrm{a}}$ & $2,91^{\mathrm{c}}$ & $3,77^{\mathrm{c}}$ & $1,15^{\mathrm{ac}}$ \\
Bambu ke cup plastik pp (bamboo to pp plastic cup) & $2,27^{\mathrm{b}}$ & $19,35^{\mathrm{d}}$ & $4,18^{\mathrm{d}}$ & na \\
Gerabah (clay) & $2,59^{\mathrm{c}}$ & $15,30^{\mathrm{c}}$ & $30,56^{\mathrm{c}}$ & na \\
Bambu ke gerabah (bamboo to clay) & &
\end{tabular}

$\overline{\mathrm{a}, \mathrm{b}, \mathrm{c}, \mathrm{d}}$ Superskrip yang berbeda pada baris/kolom yang sama menunjukkan perbedaan yang nyata $(\mathrm{P}<0,05)$

(different superscripts at the same row/column indicate significant differences $(P<0.05)$ ).

na: tidak memungkinkan untuk diuji (not available to be tested).

Tabel 9. Pengaruh berbagai jenis kemasan terhadap kadar lemak (\%) dadih susu sapi (effect of various packaging on lipid content (\%) of cow milk dadih)

\begin{tabular}{|c|c|c|c|c|}
\hline \multirow[t]{2}{*}{ Bahan pengemasan (packaging material) } & \multicolumn{4}{|c|}{$\begin{array}{l}\text { lama penyimpanan (hari) } \\
\text { (storage periode (days)) }\end{array}$} \\
\hline & 0 & 12 & 20 & 24 \\
\hline Bambu (bamboo) & $5,00^{\mathrm{a}}$ & $5,00^{\mathrm{b}}$ & na & na \\
\hline Kemasan flexypack (flexypack packaging) & $3,55^{\mathrm{b}}$ & $3,60^{\mathrm{a}}$ & $3,30^{\mathrm{c}}$ & $3,05^{\mathrm{d}}$ \\
\hline Bambu ke kemasan flexypack (bamboo to flexypack packaging) & $4,05^{\mathrm{c}}$ & $4,05^{\mathrm{d}}$ & $3,50^{\mathrm{e}}$ & $3,55^{\mathrm{a}}$ \\
\hline Cup plastik pp (pp plastic cup) & $3,90^{\mathrm{c}}$ & $3,80^{\mathrm{d}}$ & $3,50^{\mathrm{b}}$ & $3,50^{\mathrm{e}}$ \\
\hline Bambu ke cup plastik pp (bamboo to pp plastic cup) & $3,95^{\mathrm{d}}$ & $3,95^{\mathrm{e}}$ & $3,90^{\mathrm{a}}$ & $3,90^{\mathrm{b}}$ \\
\hline Gerabah (clay) & $15,72^{\mathrm{e}}$ & na & na & na \\
\hline Bambu ke gerabah (bamboo to clay) & $10,17^{\mathrm{f}}$ & na & na & na \\
\hline
\end{tabular}

penyimpanan. Walaupun demikian, besarnya kadar lemak tetap memenuhi standar SNI susu No 013141-1998 yaitu minimal 3\%. Perubahan kadar lemak diduga akibat adanya pengaruh sifat kemasan terhadap produk dan juga aktivitas $L$. casei dalam kemasan tersebut. Tingginya kadar lemak pada kemasan gerabah diduga akibat permeabilitas terhadap air tinggi sehingga cenderung menyerap air. Kadar air yang berkurang mengakibatkan tingginya total padatan produk. Peningkatan total padatan dari produk akan mengakibatkan meningkatnya kadar lemak (Taufik, 2004). 


\section{Karakteristik bakteri asam laktat (BAL)}

Hasil analisis menunjukkan adanya interaksi antara jenis kemasan dan waktu simpan $(\mathrm{P}<0,05)$ (Tabel 10). Penambahan BAL pada dadih susu sapi bertujuan untuk menjadikan produk tidak hanya sekedar sebagai susu fermentasi, namun juga sebagai minuman probiotik. Probiotik merupakan suplemen pangan yang berasal dari mikroba hidup yang menguntungkan kesehatan inangnya dengan cara memperbaiki komposisi mikroba usus. Bakteri asam laktat, khususnya yang bersifat sebagai probiotik, banyak digunakan sebagai suplemen pangan dengan berbagai manfaat bagi kesehatan (Susanti et al., 2007). Total BAL yang ada pada produk berjumlah $>10^{8} \mathrm{CFU} / \mathrm{ml}$. Jumlah total $\mathrm{BAL}$ tersebut memenuhi persyaratan sebagai minuman susu fermentasi probiotik, karena efek probiotik dapat dipertahankan jika makanan pembawa minimal mengandung jumlah mikroba probiotik sebanyak $10^{6}-10^{8} \mathrm{CFU} / \mathrm{ml}$ atau $10^{8}-10^{10} \mathrm{CFU} / \mathrm{gr}$ (preparat kering) (Suryono, 2003).

Jumlah BAL pada dadih dipengaruhi oleh kandungan gizi makanan yang dijadikan sebagai substrat dan ketersediaan oksigen. Faktor utama yang mempengaruhi pertumbuhan mikroorganisme meliputi suplai zat gizi, suhu, air dan tersedianya oksigen (Buckel et al., 1987). Bakteri probiotik tidak menghasilkan enzim yang dapat merombak hidrogen peroksida sehingga kadar oksigen yang dapat menimbulkan terbentuknya hidrogen peroksida harus dikurangi karena dapat menimbulkan kematian sel, sehingga kemasan yang memiliki permeabilitas rendah terhadap oksigen cenderung memiliki jumlah BAL lebih banyak seperti pada kemasan fleksibel dan cup plastik $p p$.

\section{Karakteristik organoleptik}

Hasil uji hedonik tersaji pada Tabel 11. Tingkat kesukaan panelis terhadap dadih susu sapi yang dikemas dalam 7 perlakuan kemasan yaitu kemasan bambu, kemasan flexypack, perlakuan bambu ke kemasan flexypack, cup plastik $p p$, bambu ke cup plastik $p p$, gerabah, dan bambu ke gerabah.

Kemasan. Hasil analisis menunjukkan bahwa perlakuan kemasan mempengaruhi tingkat kesukaan panelis terhadap kemasan $(\mathrm{P}<0,05)$. Hasil uji lanjut menunjukkan bahwa kemasan bambu berbeda nyata dengan flexypack dan cup plastik $p p$, dan menunjukkan bahwa kemasan yang paling disukai adalah cup plastik $p p$ sedangkan yang tidak disukai adalah kemasan bambu, namun kemasan gerabah, kemasan flexypack, dan cup plastik pp berbeda tidak nyata.

Kemudahan mengkonsumsi. Hasil analisis menunjukkan perlakuan kemasan mempengaruhi tingkat kemudahan panelis mengkonsumsi dadih $(\mathrm{P}<0,05)$. Hasil uji lanjut menunjukkan bahwa kemasan flexypack dan bambu berbeda tidak nyata, namun keduanya berbeda nyata dengan kemasan gerabah dan cup plastik $p p$, sementara kemasan gerabah berbeda nyata dengan kemasan cup plastik $p p$. Uji lanjut menunjukkan bahwa konsumsi paling sulit dilakukan bila dadih dikemas dengan kemasan flexypack sedangkan yang paling mudah bila dikemas dengan cup plastik $p p$.

Warna. Hasil analisis menunjukkan bahwa perlakuan kemasan mempengaruhi tingkat kesukaan para panelis terhadap warna dadih susu sapi $(\mathrm{P}<0,05)$. Hasil uji lanjut menunjukkan bahwa warna dadih pada perlakuan bambu ke kemasan flexypack berbeda nyata dengan warna pada perlakuan bambu ke gerabah, gerabah, cup plastik $p p$ dan perlakuan bambu ke cup plastik $p p$, namun warna pada kemasan flexypack berbeda tidak nyata dengan warna pada kemasan flexypack dan bambu.

Aroma. Hasil analisis menunjukkan bahwa perlakuan kemasan mempengaruhi tingkat kesukaan para panelis terhadap aroma dadih susu sapi $(\mathrm{P}<0,05)$. Hasil uji lanjut menunjukkan bahwa

Tabel 10. Pengaruh berbagai jenis kemasan terhadap total BAL (CFU/g) dadih susu sapi (effect of various packaging on total LAB (CFU/g) of cow milk dadih)

\begin{tabular}{lccc}
\hline \hline \multirow{2}{*}{ Bahan pengemasan (packaging material) } & \multicolumn{3}{c}{$\begin{array}{c}\text { lama penyimpanan (hari) } \\
\text { (storage periode (days)) }\end{array}$} \\
\cline { 2 - 4 } & 0 & 4 & 8 \\
\hline Bambu (bamboo) & $3,3 \times 10^{10 \mathrm{a}}$ & $\mathrm{na}$ & $\mathrm{na}$ \\
Kemasan flexypack (flexypack packaging) & $1,7 \times 10^{11 \mathrm{a}}$ & $7,2 \times 10^{11 \mathrm{a}}$ & $3,9 \times 10^{10 \mathrm{a}}$ \\
Bambu ke kemasan flexypack (bamboo to flexypack packaging) & $2,8 \times 10^{11 \mathrm{a}}$ & $1,0 \times 10^{11 \mathrm{a}}$ & $7,3 \times 10^{9 \mathrm{a}}$ \\
Cup plastik pp (pp plastic cup) & $1,7 \times 10^{10 \mathrm{a}}$ & $3,6 \times 10^{10 \mathrm{a}}$ & $2,4 \times 10^{10 \mathrm{a}}$ \\
Bambu ke cup plastik pp (bamboo to pp plastic cup) & $8,7 \times 10^{10 \mathrm{a}}$ & $4,9 \times 10^{11 \mathrm{a}}$ & $1,9 \times 10^{10 \mathrm{a}}$ \\
Gerabah (clay) & $4,4 \times 10^{10 \mathrm{a}}$ & $\mathrm{na}$ & $\mathrm{na}$ \\
Bambu ke gerabah (bamboo to clay) & $2,3 \times 10^{11 \mathrm{a}}$ & $\mathrm{na}$ & $\mathrm{na}$ \\
\hline
\end{tabular}

a Superskrip yang berbeda pada baris/kolom yang sama menunjukkan perbedaan yang nyata $(\mathrm{P}<0,05)$

(different superscript at the same row/column indicate significant differences $(P<0.05)$ ).

na: tidak memungkinkan untuk diuji (not available to be tested). 
Tabel 11. Uji organoleptik dadih susu sapi (organoleptic test of cow milk dadih)

\begin{tabular}{lllllllll}
\hline \multirow{2}{*}{ Parameter } & \multicolumn{7}{c}{ Jenis kemasan (kind of packaging) } \\
\cline { 2 - 7 } & 1 & 2 & 3 & 4 & 5 & 6 & 7 \\
\hline Kemasan (packaging) & $3,36^{\mathrm{a}}$ & $4,08^{\mathrm{bc}}$ & $4,28^{\mathrm{bc}}$ & $3,68^{\mathrm{ab}}$ & $4,04^{\mathrm{bc}}$ & $4,36^{\mathrm{c}}$ & $3,68^{\mathrm{ab}}$ \\
Kemudahan mengkonsumsi (easy to consume) & $3,04^{\mathrm{a}}$ & $2,64^{\mathrm{a}}$ & $4,72^{\mathrm{b}}$ & $4,00^{\mathrm{c}}$ & $2,88^{\mathrm{a}}$ & $4,72^{\mathrm{b}}$ & $4,00^{\mathrm{c}}$ \\
Warna (color) & $4,04^{\mathrm{ab}}$ & $4,00^{\mathrm{ab}}$ & $3,28^{\mathrm{cd}}$ & $3,52^{\mathrm{ac}}$ & $4,36^{\mathrm{b}}$ & $3,80^{\mathrm{ad}}$ & $2,84^{\mathrm{c}}$ \\
Aroma (aroma) & $2,92^{\mathrm{abc}}$ & $3,04^{\mathrm{bc}}$ & $2,28^{\mathrm{a}}$ & $2,76^{\mathrm{ac}}$ & $3,48^{\mathrm{b}}$ & $2,92^{\mathrm{abc}}$ & $3,00^{\mathrm{bc}}$ \\
Rasa (taste) & $2,64^{\mathrm{bc}}$ & $2,44^{\mathrm{c}}$ & $1,68^{\mathrm{a}}$ & $3,12^{\mathrm{b}}$ & $2,76^{\mathrm{bc}}$ & $2,48^{\mathrm{c}}$ & $2,72^{\mathrm{bc}}$ \\
Tekstur (texture) & $3,28^{\mathrm{bc}}$ & $2,80^{\mathrm{ac}}$ & $3,00^{\mathrm{ac}}$ & $3,32^{\mathrm{bc}}$ & $3,24^{\mathrm{bc}}$ & $3,80^{\mathrm{b}}$ & $2,44^{\mathrm{a}}$ \\
Penerimaan umum (general acceptance) & $2,96^{\mathrm{b}}$ & $2,80^{\mathrm{b}}$ & $2,28^{\mathrm{a}}$ & $3,08^{\mathrm{b}}$ & $3,08^{\mathrm{b}}$ & $3,08^{\mathrm{b}}$ & $2,68^{\mathrm{ab}}$ \\
\hline
\end{tabular}

${ }^{a, b, c, d}$ Superskrip yang berbeda pada baris yang sama menunjukkan adanya perbedaan yang nyata $(\mathrm{P}<0,05)$

(different superscripts at the same row indicate significant differences $(P<0.05)$ ).

1 : bambu (bamboo)

2: cup plastik pp (pp plastic cup)

3 : bambu ke flexypack (bamboo to flaxypack)

4 : bambu ke cup plastik pp (bamboo to pp plastic cup)

aroma pada cup plastik $p p$ berbeda nyata dengan aroma pada perlakuan bambu ke gerabah, kemasan flexypack, dan perlakuan bambu ke kemasan flexypack. Aroma dadih pada cup plastik pp berbeda tidak nyata dengan aroma pada gerabah, bambu, dan perlakuan bambu ke cup plastik pp. Aroma dadih yang paling disukai adalah pada perlakuan kemasan bambu ke kemasan flexypack dan yang tidak disukai adalah aroma pada cup plastik $p p$. Aroma susu fermentasi disebabkan oleh adanya pembentukan senyawa asetaldehid, diasetil, asam asetat, serta kelompok asam lainnya dalam jumlah kecil. Selain itu kandungan lemak susu dapat berpengaruh terhadap pembentukan komponen flavor produk. Oleh karena itu, kemasan yang dapat mempertahankan senyawa-senyawa tersebut akan menyebabkan aroma dadih lebih disukai.

Rasa. Hasil analisis menunjukkan bahwa perlakuan kemasan mempengaruhi tingkat kesukaan para panelis terhadap rasa dadih susu sapi $(\mathrm{P}<0,05)$. Hasil uji lanjut menunjukkan bahwa rasa pada kemasan cup plastik $p p$ berbeda nyata dengan rasa pada perlakuan kemasan lainnya, sedangkan rasa pada kemasan gerabah berbeda tidak nyata dengan rasa pada perlakuan bambu ke kemasan flexypack, bambu ke gerabah, dan bambu, namun rasa pada perlakuan bambu ke kemasan flexypack ini berbeda nyata dengan rasa pada kemasan fleksibel dan perlakuan bambu ke cup plastik pp. Rasa dadih paling disukai pada kemasan gerabah dan yang tidak disukai pada kemasan cup plastik $p p$. Hal ini diduga disebabkan oleh dadih pada kemasan cup plastik memiliki rasa yang sangat asam. Dadih yang sangat asam rasanya berada di bawah ambang cita rasa yang dapat dideteksi oleh indera pengecap manusia. Keasaman susu fermentasi yang dapat dideteksi jika pHnya berada pada kisaran 4,4 - 4,6 (Taufik, 2005).

\author{
5 : flexypack \\ 6 : gerabah (clay) \\ 7 : bambu ke gerabah (bamboo to clay)
}

Tekstur. Hasil analisis menunjukkan bahwa perlakuan kemasan mempengaruhi tingkat kesukaan para panelis terhadap tekstur dadih susu sapi $(\mathrm{P}<0,05)$. Hasil uji lanjut menunjukkan bahwa tekstur pada perlakuan bambu ke gerabah berbeda nyata dengan tekstur pada perlakuan bambu ke kemasan flexypack, bambu, gerabah, dan bambu ke cup plastik $p p$, namun tekstur pada perlakuan bambu ke gerabah berbeda tidak nyata dengan tekstur pada kemasan flexypack dan cup plastik $p p$. Demikian halnya dengan tekstur pada perlakuan bambu ke cup plastik $p p$ berbeda tidak nyata dengan tekstur pada kemasan gerabah, bambu dan perlakuan bambu ke kemasan flexypack. Tekstur yang paling disukai pada perlakuan kemasan bambu ke cup plastik $p p$ dan yang tidak disukai pada perlakuan kemasan bambu ke gerabah.

Penerimaan umum. Hasil analisis menunjukkan bahwa perlakuan kemasan mempengaruhi tingkat kesukaan panelis terhadap penerimaan umum dadih susu sapi $(\mathrm{P}<0,05)$. Hasil uji lanjut menunjukkan bahwa secara umum dadih pada cup plastik $p p$ berbeda tidak nyata dengan dadih pada perlakuan kemasan bambu ke gerabah namun dadih pada cup plastik $p p$ berbeda nyata dengan dadih pada 5 perlakuan kemasan yang lain. Secara umum dadih yang paling disukai adalah dadih susu sapi yang dikemas pada perlakuan kemasan bambu ke cup plastik $p p$.

\section{Kesimpulan}

Jenis kemasan flexypack dan cup plastik $p p$ sampai hari ke 24 menunjukkan karakteristik dadih yang paling baik. Dari segi ekonomis, kemasan cup plastik $p p$ lebih efisien dan murah. Karakteristik dadih sapi yang dibuat menggunakan kemasan cup plastik $p p$ antara lain total asam $(1,60 \%), \mathrm{pH}(3,88)$, 
viskositas $(351,43 \mathrm{cP})$, total padatan $(14,75 \%)$, kadar air $(85,25 \%)$, kadar abu $(0,90 \%)$, kadar protein $(2,43 \%)$, kadar lemak $(3,68 \%)$, total $\mathrm{BAL}$ $\left(8 \times 10^{11} \mathrm{CFU} / \mathrm{g}\right)$, dengan total $\mathrm{BAL}>10^{8} \mathrm{CFU} / \mathrm{ml}$, sehingga dadih susu sapi yang diperoleh tergolong sebagai minuman probiotik. Uji organoleptik menunjukkan kemasan cup plastik $p p$ memiliki keunggulan dalam atribut kemasan dan kemudahan mengkonsumsi.

\section{Daftar Pustaka}

Anonimus. 1995. Standar Mutu Susu Pasteurisasi. SNI 01-3951-1995. Badan Standardisasi Nasional. Jakarta.

Anonimus. 1998. Standar Mutu Susu Segar. SNI 01-3141-1998. Badan Standardisasi Nasional. Jakarta.

Anonimus. 2007. Kemasan Fleksibel. Jakarta : Direktorat Jenderal Industri Kecil Menengah Departemen Perindustrian.

Antherton, H.V. dan J.A. Newlander. 1980. Chemistry and Testing of Dairy Products. AVI Pub. Inc. Westport. Connecticut.

AOAC (Association of Official Analytical Chemist). 1984. Official Methode of Analysis. $14^{\text {th }}$ ed. AOAC. Arlington. Washington D. C.

Apriyantono, A.D. Fardiaz, N.L. Sedarnawati, dan S. Budiyanto. 1989. Analisa Pangan. Pusat Antar Universitas Pangan dan Gizi Institut Pertanian Bogor.

Beukes, E.M., H.B. Bernie, dan F.M. Johannes. 2000. The microbiology of south african traditional fermented milks. International Journal of Microbiology 63 (2001): 189-197.

Buckel, K.A., R.A. Edwards, G.H. Fleet, dan M. Wooton. 1987. Ilmu Pangan. UI Press. Jakarta.

Dzarnisa. 1999. Flavor dan Kualitas Dadih Susu Sapi yang Dipasteurisasi dan Disimpan pada Suhu Kamar dan Lemari Es. Program Pasca Sarjana. IPB. Bogor.

Fardiaz, S. 1989. Mikrobiologi Pangan I. PAU. Jurusan Teknologi Pangan dan Gizi. Fakultas Teknologi Pertanian. IPB. Bogor.

Julianto. 2006. Kualitas dan Daya Simpan Dadih Susu Sapi Hasil Fermentasi dengan Lactobacillus plantarum yang Dikemas serta Disimpan Pada Suhu Berbeda. Jurusan Ilmu Produksi Ternak. Fakultas Peternakan. Institut Pertanian Bogor.

Pato, U. 2003. Potensi bakteri asam laktat yang diisolasi dari dadih untuk menurunkan resiko penyakit kanker. Jurnal Natur Indonesia 5(2): 162-166.
Rusfidra, A. 2006. Dadih/Dadiah, Susu Kerbau Fermentasi Mampu Menurunkan Kolesterol. Available at www. Cimbuak.net. Accession date: 12 Agustus 2008.

Saleh, E. 2004. Teknologi Pengolahan Susu dan Hasil Ikutan Ternak Program Studi Produksi Ternak Fakultas Pertanian Universitas Sumatera Utara. Digitized by USU digital library.

Sayuti, K. 1992. Studi Nilai dan Konsumsi Makanan Tradisional Dadih di Sumatera Barat Studi Kasus di Kecamatan Lembah Gumanti. Program Pascasarjana Gizi Masyarakat dan Kesehatan Keluarga. Institut Pertanian Bogor.

Sisriyenni, D. dan Yayu. 2004. Kajian kualitas dadih susu kerbau di dalam tabung bambu dan tabung plastik. Jurnal Pengkajian dan Pengembangan Teknologi Pertanian 7(2): 171-179.

Soekarto, S.T. dan M. Hubies. 1991. Petunjuk Laboratorium Metode Penelitian Indrawi. Pusat Antar Universitas Pangan dan Gizi. Institut Pertanian Bogor.

Sugitha, I.M. 1995. Dadih Makanan Tradisional Minang, Manfaat dan Khasiatnya. Dalam Widyakarya Nasional Khasiat Makanan Tradisional. Kantor Menteri Negara Urusan Pangan RI. Jakarta. Hal: 532-540.

Soeharsono. 1996. Fisiologi Laktasi. Universitas Padjajaran. Bandung.

Sunarlim, R. dan S. Usmiati. 2006. Sifat mikrobiologi dan sensori dadih susu sapi yang difermentasi menggunakan Lactobacillus plantarum dalam kemasan yang berbeda. Buletin Peternakan 30(4): 208-216.

Surono, I.S. and A. Hosono. 1996. Antimutagenicity of milk cultured with lactid acid bacteria isolated from dadih. Milchwissenschaft 51(19): 493-497.

Suryono. 2003. Dadih: Produk Olahan Susu Fermentasi Tradisional Yang Berpotensi Sebagai Pangan Probiotik. Pengantar Falsafah Sains. Program Pascasarjana/S3. Institut Pertanian Bogor.

Susanti, I., W.K. Retno, dan I. Fatim. 2007. Uji sifat probiotik bakteri asam laktat sebagai kandidat bahan pangan fungsional. Jurnal Teknologi dan Industri Pangan 18(2): 89-95.

Syarief, R. dan A. Irawati. 1988. Pengetahuan Bahan Pangan. PT. Mediyatma Sarana Perkasa. Jakarta.

Taufik, E. 2004. Dadih susu sapi hasil fermentasi berbagai starter bakteri probiotik yang disimpan pada suhu rendah : karakteristik kimiawi. Media Peternakan 27(3): 88-100. 
Taufik, E. 2005. Dadih susu api hasil fermentasi berbagai starter bakteri probiotik yang disimpan pada suhu rendah: II. karakteristik fisik, organoleptik, dan mikrobiologi. Media Peternakan 28(1): 13-20.

Yudoamijoyo, R. M., T. Zoelfikar, S.R. Herastuti, A. Tomomatsu, A. Matsuyama, and A. Hosono. 1983. Chemical and microbiological aspect of dadih in Indonesia. Japanese J. of Dairy and Food Science 32(1): 1-10.

Winarno, F.G. 1987. Mutu, Daya Simpan, Transportasi dan Penanganan Buah-buahan dan Sayuran. Konferensi Pengolahan Bahan Pangan dalam Swasembada Eksport. Departemen Pertanian Jakarta. 